\title{
Genocide: on the edge of an act called mass murder
}

\author{
Ranabir Samaddar ${ }^{1}$
}

Accepted: 15 December 2021 / Published online: 8 February 2022

(c) The Author(s), under exclusive licence to Springer Nature Limited 2022

\begin{abstract}
The Problems of Genocide points to a displace site of globalism, namely globalised mass murders. The book suggests two parallel stories, namely the unfolding of the theme of mass murders in global politics in the twentieth century and the ways race has become integrated with the phenomenon of modern liberal nations. The question of mass murders as a problem for global governance became acute only when mass murder created a crisis or took place in the context of a crisis. The book presents a detailed historical account of the context in which genocide emerges as a crucial legal concept to account for the large scale killings of populations in our time. Yet, as the book shows, the concept has remained highly problematic owing to the deeply hierarchised notion of mass murders.
\end{abstract}

Keywords Genocide $\cdot$ Mass killings $\cdot$ Famines $\cdot$ Race $\cdot$ Liberal security $\cdot$ Dialogic justice

\section{Search for a perfect word for mass deaths}

The problems of genocide: permanent security and the language of transgression is a testimony to Dirk Moses' (2021) outstanding scholarship on genocide. This vast scholarship, however, is not deployed here to showcase author's erudition. It is used in a critical way to make genocide, hitherto accepted as a legal, political, and moral concept, a problem for our understanding. Hereafter genocide, a notion that had settled the conscience of moralists and good liberal souls, will have an uncertain life. We all shall have to ask: What is the frontier of killing? Is there any hierarchy in the violation of human rights? In view of the quarrels over making right slots for right kind of human destruction, we may slightly rephrase Fyodor Dostoyevsky in Brothers Karamazov and say of ourselves: the more we love humanity in general the less we are concerned about the lives of actual men and women. In our dreams, we often make plans for the service of humanity, and yet we can perfectly say that this mass

Ranabir Samaddar

rsamaddar@hotmail.com

1 Mahanirban Calcutta Research Group, Calcutta, India

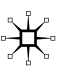


killing is not as ultimate as that one. Hence, we are all against genocide even though mass killings may continue with our involvement in one way or another.

The links among the issues of genocide, killings of Jews, survival, and recognition of "small nations" in an age of the global emergence of nationalism and nationstates become clear as Dirk Moses connects the dots and brings to us the account of how mass murder as a phenomenon became a problem for the international order. The humanitarian and the global are intertwined in this historical narrative. We have here another insight: the relation between, on the one hand, the rise in modern mass murders, politics around lives, and claims to legitimacy around destroying or protecting lives and, on the other, the emergence of modern humanitarianism. The book may be considered also as an interrogation of modern humanitarianism. Humanitarianism as distinct from philanthropy, charity, piety, and sympathy is a distinct ideology that draws at least in our time much from human rights.

Yet it does not stop at that. It grows from sentiment, foregrounds an ethical sense of responsibility, it develops a consciousness of rights, and becomes an idea unto itself, an ideology that will require mega institutions and laws. Dirk Moses has crafted a detailed historical account of the strange journey of an idea. The crucible of this journey is of course the real history of mass murders and battle of perceptions and involvements in these murders. This account thus is not simply the history of an idea-genocide-but one laced with real-life political events of killings, debates over those killings, the legitimating and de-legitimating strategies around them, and the emergence of an international discourse on these killings hitherto considered as nation-centric events. Michel Foucault reminded us of the "citizen massacres" that were essential for the birth of nation-states (1978: 136-137).

In this context, humanitarianism became essential for modern forms of global governance. The liberal way to rule and the liberal way to war are linked in more than one way in this connected history of the nation-states and global governance. Moses' account of the simultaneously happening Indian partition and the partition of Palestine throws light on the citizen-massacres as an almost secular law of history. He also notes that these massacres escaped the opprobrium of genocide. The ground for the humanitarian was prepared in unnoticed ways through the history of hierarchized mass violence, which excluded events such as famines (say, the Irish Famine in 1840s or the Bengal Famine of 1943) or epidemics as events of mass violence from the purview of legal criminality.

Yet the situation is changing at least in the postcolonial context. Noticeably, an Indian High Court in the wake of the ravaging return of the COVID pandemic in the country in April 2021 remarked, "The death of Covid-19 patients just for nonsupplying of oxygen to the hospitals is a criminal act and not less than a genocide... how can we let people die in this way?" (The Wire, 2021).

Consider the term "herd immunity" in this context. The pseudo-Darwinian theories of "herd immunity" have basically meant calculating and arbitrating the number of deaths that can be allowed to ensure the lives of the rest. Indeed, biological security like other security games plays on the principle of determination of ratio. We should not be surprised that modern governmentality is essentially a matter of 
calculation of various options and possibilities and determination of ratio between options, alternatives, and possibilities.

Discussions of genocide and crime against humanity as a general legal question thus inevitably cross the academic boundary between studies of genocide and studies of famines and mass health disasters. In the postcolonial memory of deaths, the boundaries between say the Jallianwala Bagh massacre of around 400 unarmed civilians by the colonial military forces (1919), the Bengal Famine (1943) in which about 2.5 million people perished, and the Great Calcutta Killings (1946) which devoured by a conservative estimate 4000 people, are blurred. From the angle of boundaries of concepts, this is transgression; from the angle of memory, this is the chiaroscuro of mass deaths taking place at frequent intervals. In some cases, you may identify the perpetrator of violence, in some cases, you cannot (as in the Bengal Famine and now the thousands of COVID deaths). There is no single identifiable perpetrator of death and destruction.

At one level thus, terms like genocide or crime against humanity are legal terms carrying the imprint of a history. At another level, they acquire their specific and distinct lives - shaping events, memory, and our understanding. For that reason, commentators have been moved to invoke "crime against humanity" in seeing how hundreds in India died owing to lack of primary healthcare needs (Aatreya, 2021).

Appropriately, therefore, Moses begins the book by noting the issue of the inadequacy of the term genocide and the emergence of complementary terms such as "crime against humanity," "crime of all crimes," and "crime of atrocity." He shows the inconclusive nature of these supplementary terms. Following Lawrence Douglas, Moses calls the discursive situation as one of "the atrocity paradigm" (2021: 20-23).

But then in the actual hell where nations descend, it matters little whether you call it genocide, or a crime against humanity. In this hell, you will be required to answer when and how has it become so crucial to know how death is produced? The question of historical knowledge is deadly. With our received idea of "crime," we ignore the fact that people are exterminated not only from genocide and what is called "ethnic cleansing." As I indicated above, deaths of large populations can happen differently.

Genocide in this way brings in its opposite, the question of life, the strategy of saving some lives by organising some deaths. From Malthus onward, bourgeois historical knowledge of bio-politics has been built on an obfuscation of the principle of determination of the ratio between expendable lives and lives to save because the latter category will be that of productive lives. If the ratio was being hitherto determined by nations at nation-state level, today the ratio is being globally determined-whether in case of the Mediterranean boat crossings or the Rohingyas at sea or the health safety of the human species as witnessed in the gross inequity in global vaccine availability. In each of these cases, the ratio of lives to be expended and secured is being determined globally. Extermination of Jews happened at the same time when conquered population groups were being put to work in the German production machines as eight decades earlier when the United States when the extermination of Native Americans was accompanied and followed by massive import of contracted labor from China, a generation of whom perished in the construction of 
railway lines. Seen in this light, the small nations of, say, Eastern Europe, other subordinated population groups, suppressed races, subjects of Atlantic slavery, and the Jews and Roma people formed a large continuum of population groups that could be considered expendable when found unsuitable to be used as raw labor.

\section{Parallel stories of race battles and modern crises}

If small nations form one of the axes of Moses' book, the other is race. We know that race superiority, race discrimination, racial hatred, racial destruction, racial consciousness, racial typologies, racial histories, racial hierarchies, racial domination, and racial violence have marked the functioning of state in an age of liberty, equality, fraternity, and global colonialism. Dirk Moses shows how race like the other theme of small nations has enabled modern mass murders at frequent intervals through the last one and half centuries. In fact, a lesser narrated story of the reality of state formation in vast parts of the world is the way race acted as a fulcrum on which small nations built themselves. These small nations, while crying out for recognition, discriminated against and suppressed various "races" within Jews, nonSlavs, Roma, Muslims, non-Orthodox Christian, and non-Turk subjects.

Clearly, race has functioned as a scepter driving a wedge through the landscape of universalism and what Moses terms "liberal permanent security." Racism did not begin with the modern age but acquired greater potency as a reason for mass murder as various fault lines appeared in the permanent drive for colonial conquest by stronger countries and powers. The Polish lawyer Raphael Lemkin's efforts to make the world recognize racially motivated destruction as an international crime was part of producing a new type of historical knowledge about the function of race in modern international politics. Moses' detailed description of Lemkin's efforts tells us how the new historical knowledge was formed in the wake of the massacres and deportations of Armenians during the First World War I and the absence of international law to prosecute the Ottoman leaders responsible for acts. This new historical knowledge played a crucial role in creating a hierarchy of civilian destruction. It formed the hinge between the global governing power in the post-WWII age and the silent recognition of the fact that the creation of this power owed among others to the horrific realization that the victory in this war had come only on the basis of defeating the enemy in a race war. In doing so, it hid the reality of wartime civilian casualties (as in bombing), colonial wars, mass extermination in famines, and the continuing histories of enmities and friendships. Only racially motivated mass killings became the subject of law.

It is no accident that Lemkin's new knowledge hid quite many realities while setting up new themes for rational global governance. Race was now banished from the arena of governance. Race as a reality was over, the world would have to fight racism (Balibar, 1991). Meanwhile, in the post-war, post-racist world, the reconstitution of nation-states was achieved on the basis of a citizen/stateless duality. The immigrant became gradually the other race. The mutual determination of racism and nationalism must not miss our eyes. 


\section{Life of full security or the life of the daily practices of friendship}

Security is a never-ending anxiety for all nations. Moses shows the presence of the theme of security always overwhelms and in turn is subsumed by the question of genocide and now crimes against humanity. It is a concentric circle continuously drawing inward and expanding out to remain a valid concept. The entire history of security with its debates on proportionality, just ways and just motives to war, collateral damage, use of tactical nuclear weapons to achieve focused damage to the enemy, maintaining secure borders, securing a nation with right size of territory and right mix of population, and securitizing food, climate, environment, migration, climate, water-in fact, every conceivable asset of the earth-is a history of discovering and mending fault lines in the architecture of security and rediscovering yet more. Policies of macro-security have produced micro-insecurities all around.

The liberal state claimed that it had broken the back of pre-modern networks of power based on clan, tribe, race, royal lineage, religion, and created a secular structure of rule based on a republican identity of voter, citizenship, and the institution of universal suffrage. Neoliberal regimes understand the limits of the liberal solution to the ongoing wars of contentious politics. They co-opt non-republican networks of power in the market-based networks. While this may have solved at least temporarily some of the problems of liberal security paradigm, we are now in a situation where the reality of the intermeshed networks of power that act as the foundation of global governance produces the virtual possibility of seditions and riots all around. The daily life of the state is captive to its virtual life that is framed by sedition and riot.

The neo-liberals would like to have a perfect solution to the conundrum. On one hand, they would like the conditions to be such that genocide becomes increasingly an obsolete concept, or at least something that society can no longer be accused of committing; on the other hand, necessary killing and expenditure of lives continue so that "societies are defended." Force will be ready for deployment as always. We have here a combination of the imperial theme of power and the modern theme of government that addresses the problems of life and population as the object of a policy of security. This combination makes the language of security increasingly flexible. Security is achieved only through a transgression of its given language. The language of transgression becomes the language of security of the neoliberal time. This is how security can become permanent. Thereby neoliberal rule makes the legal quest for justice an impossible category by itself. There is no permanent security in as much as there is no solution to the secular law of transgression of liberal security norms.

Therefore, the challenge is how do we link the concept of security with dialogue, contingency, and the notion of a daily practice of friendship - all of which mean accepting uncertainties of life, a readiness to live "uncertainly" that is to say "live dangerously"? In such condition of flexibility, recognition of rights cannot be a onetime affair. The recognition will be in a continuous mode as if the rights movement is a matter of daily plebiscite. 
The problems of genocide is a rewarding book because while solving some important questions the book opens up to new issues to think ahead of. For example, recall the tireless efforts of the Spanish jurist Bartolome Clavero (2011) to bring a special international law on the rights of the indigenous peoples in the light of the limits of the Genocide Convention (1948). His research tells us how the expropriation of the property of the American Indians by the states joining hands to form the United States was crucial in establishing the rule of property as laid down by the US constitution. Eight letters only, but Clavero shows (2008), they have a long history to unravel.

To imagine that history, perhaps we need to imagine a different form of justice, which for lack of better term we may provisionally call, minimal justice, which is dialogic justice. At least five principles can be culled out from the history of last hundred years: (1) recognition of past injustices, (2) jointly determined compensation for past injustices; (3) guarantee that such injustices will not happen again; (4) joint mechanisms to ensure that guarantee; (5) and an acknowledgment that not all were affected equally, and hence the guarantee that the principle of autonomy is universal, and that the operation of achieving justice must continue deeper within the victim societies.

\section{References}

Aatreya, S. S. (2021). Why India's Covid-19 catastrophe is indeed a 'crime against humanity'. The Wire, 13 May. https://thewire.in/health/why-indias-covid-19-catastrophe-is-indeed-a-crime-against-human ity. Accessed 4 June.

Balibar, E. (1991). Chapter 1: Is there a 'neo-racism'? and Chapter 3: Racism and nationalism. In I. Wallerstein (Ed.), Race, nation, class: Ambiguous identities. London: Verso.

Clavero, B. (2011). Study on international criminal law and the judicial defence of Indigenous peoples' rights. Report presented by the Special Rapporteur at the Permanent Forum on Indigenous Issues, UN Economic and Social Council; 16-27 May, Tenth session, New York, https://www.refworld.org/ pdfid/4dbfc6862.pdf. Accessed 25 May 2021.

Clavero, B. (2008). Genocide or ethnocide, 1933-2007: How to make, unmake, and remake law with words. Giuffre.

Foucault, M. (1978). The history of sexuality: Volume I: An introduction, trans. Robert Hurley. New York: Pantheon Books.

Moses, A. D. (2021). The problems of genocide: permanent security and the language of transgression. Cambridge University Press.

The Wire. (2021). Covid-19 patients dying due to oxygen shortage is not less than a genocide: Allahabad HC. 5 May 2021. https://thewire.in/law/covid-19-oxygen-shortage-genocide allahabad-high-court. Accessed 4 June 2021

Publisher's Note Springer Nature remains neutral with regard to jurisdictional claims in published maps and institutional affiliations. 